\title{
Renewable resources of energy in northern Baja California, Mexico
}

\author{
M. Quintero-Núñez ${ }^{1}$, A. Sweedler ${ }^{2}$ \& S. Tanaka ${ }^{2}$ \\ ${ }^{1}$ Instituto de Ingeniería, Universidad Autónoma de Baja California, \\ Baja California, México \\ ${ }^{2}$ Center for Energy Studies, San Diego State University, San Diego, CA, \\ USA
}

\begin{abstract}
In Mexico, the Comisión Federal de Electricidad (CFE) is a government entity created to generate and distribute energy in Mexico. CFE is operating a $720 \mathrm{MW}$ capacity geothermal power plant at Cerro Prieto, located in the valley of Mexicali, Baja California, Mexico. Wind energy in Baja California is not now being exploited. It is potentially productive in some areas of the Rumorosa mountain range and at the Cañon de San Martin in the Valle de la Trinidad. Wind pattern measurements have been carried out and investors' interest is growing for wind farms of different sizes (1500 MW, $250 \mathrm{MW}, 50 \mathrm{MW})$. Solar radiation in Baja California is quite significant. Solar photovoltaic (PV) electricity is widely used for lighting, communications, and appliances throughout the state of Baja California in rural areas and small towns not connected to an electric grid. In order to exploit the full potential of renewable energy resources in this border region with California, EUA, a series of barriers and drivers are addressed. While significant technical potential for renewable energy exists in Baja California, additional study is required to fully characterize the resources and refine estimates.

Keywords: renewable energy, Baja California-California border region, Mexico, geothermic, wind energy.
\end{abstract}

\section{Introduction}

The Secretariat of Energy [1] encouraged the National Energy Savings Commission (CONAE) to promote the development of renewable energies in 
Mexico to reduce its dependence on hydrocarbon fuels. In 1966 CONAE, along with the National Association for Solar Energy (ANES), organized a forum to discuss the potential steps to promote renewable energy sources. The result was the creation of the Advisory Council for the Promotion of Renewable Energies (COFER). This group is made up of representatives from industry, commerce, academia, government, and development banks. The aim of COFER is to promote the use of renewable sources of energy in Mexico within a market framework. It also serves as an advisory group to identify projects and for the design and development of programs and policy related to renewable energy, including small hydro, solar, biomass, and geothermal. SENER (1998) estimates that by 2008 close to $559 \mathrm{MW}$ will be installed in such systems, producing approximately $1,836 \mathrm{GWh} / \mathrm{y}$.

\section{Characteristics of Baja California}

The state of Baja California (Fig. 1) is located in the northwest part of the peninsula of the same name with approximately $500 \mathrm{~km}$ of length from the international line with California, USA ( $33^{\circ}$ latitude North) down to parallel $28^{\circ}$ in the south. It has a surface of $70,113 \mathrm{~km}^{2}$ which represent $3.75 \%$ of the total surface of the country. It is formed by mountains, hillsides, central valleys and coasts, besides a very discontinuous litoral on the Pacific Ocean.

The state of Baja California is characterised by the existence of two main meteorological regimes that divide the climate: a warm and dry during the spring, summer and the beginning of fall, and the other in winter with relatively humid and slightly cold [2].

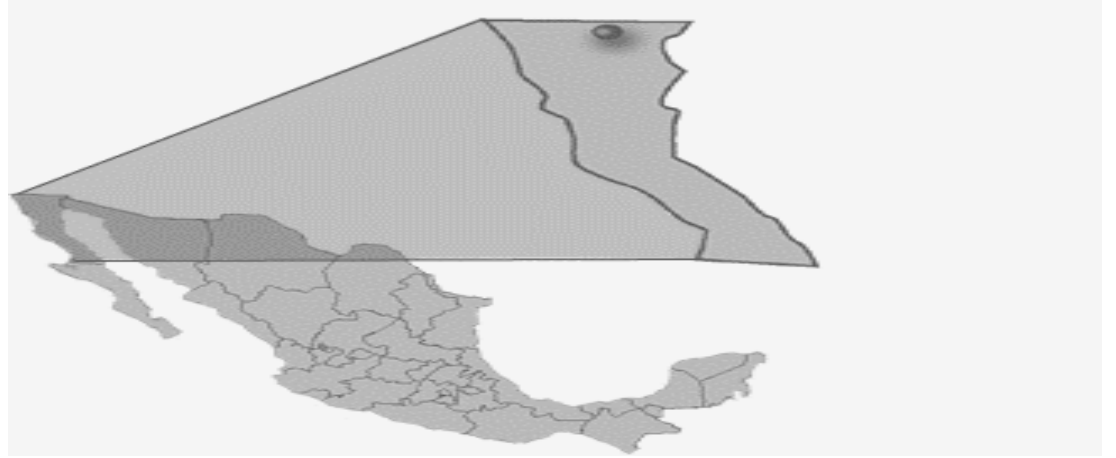

Figure 1: $\quad$ The state of Baja California is located in the northwest of Mexico.

\section{Legal framework}

Each renewable energy source requires an adequate legal and regulatory environment that favors its development. Mexico's existing legal framework allows power generation projects using renewable energy under self-supply, 
small production, independent construction, and export schemes. The Public Service for Electric Energy law does not constrain power generation to a specific technology. Even though environmental costs are not expressly considered when pricing the Mexican electric market, there are a few legal provisions that promote the use of renewable energy.

\section{Geothermal technical potential}

The Federal Electricity Commission (CFE) is a federal government entity created to generate and distribute electric energy in Mexico (Constitucion Politica de los Estados Unidos Mexicanos, 1988) [3]. In 1982 CFE created the Geothermal Electrical Projects division whose specific function is to coordinate all geothermal-related activities in Mexico. The following is a brief summary of geothermal activity in the valley of Mexicali, currently under development by the Mexican government for the production of electricity.

Cerro Prieto (Mexicali, Baja California) is the most important site being developed by the Mexican government. It is located in the Mexicali Valley (115.16 longitude west, 32.25 latitude north) between the Pacific and American tectonic plates and near the San Andreas Fault. The plain is a delta, and the geological area is composed of unconsolidated clays, sand, and gravel that rest on sedimentary rocks of sandstone, lutites, and limonites.

Currently the site has a capacity of $720 \mathrm{MW}$ distributed over four plants, Cerro Prieto I-IV (180, 220, 220, and 100 MW respectively). According to Alonso 1988 [4], the Cerro Prieto geothermal reservoir has an estimated capacity of 1,200 MW and a proven capacity of $840 \mathrm{MW}$. Since $720 \mathrm{MW}$ of the $840 \mathrm{MW}$ of proven capacity have been developed, the technical potential for new capacity is $120 \mathrm{MW}$.

\section{Energy sources in Mexico}

To date, geothermal energy, along with other alternative sources such as solar, wind, marine, and biomass, have contributed marginally to the energy balance in Mexico. In the National Energy Balance of Mexico for 2004 [5], geothermal energy represents only $0.6 \%$ and wind energy is not significant.

\subsection{Wind energy}

The Center for Higher Education and Research of Ensenada (CICESE) carried out a project titled, "Wind Energy in Potentially Productive Areas in Baja California." This study was based on available data for the Rumorosa mountain range in relation to meteorology, climatology, geography, and topography.

The objective of the study was to determine wind patterns for a one year period, possible locations for the establishment of wind farms, recommendations for the construction of sustainable and profitable wind farms.

The evaluation criteria to determine the potential production areas included the following: 
* Average annual wind magnitude (minimum of 5.5 to $6 \mathrm{~m} / \mathrm{s}$ )

* Proximity of energy transmission lines

* Proximity of centers of energy consumption

Daily wind registries (velocity and direction) were obtained from seven meteorological stations within the study area. Monthly and annual averages were projected after processing the data. The result was that high intensity winds are produced during the day, coinciding with the time of greater demand of electricity in urban areas. Table 2 shows a list of the potential areas where this resource can be developed. The study area is shown if Figure 2.

Table 1: $\quad$ Wind energy locations in Baja California, Mexico.

\begin{tabular}{|l|l|l|l|l|}
\hline Station & $\begin{array}{l}\text { Ave. Wind } \\
\text { Speed (knots) }\end{array}$ & $\begin{array}{l}\text { Ave. Wind } \\
\text { Speed } \\
(\mathrm{M} / \mathrm{s})\end{array}$ & $\begin{array}{l}\text { Standard } \\
\text { Deviation }\end{array}$ & $\begin{array}{l}\text { Energy } \\
\left(\text { watts } / \mathrm{m}^{2}\right)\end{array}$ \\
\hline Pino Suárez & 20.2 & 10.9 & 4.5 & 1299.6 \\
\hline Jacumé & 15.5 & 8.3 & 3.7 & 581.6 \\
\hline La Rumorosa & 14.9 & 8.0 & 4.0 & 516.4 \\
\hline El Hongo & 12.0 & 6.5 & 2.6 & 274.0 \\
\hline El Pinal & 11.7 & 6.3 & 2.9 & 254.7 \\
\hline La Puerta & 11.5 & 6.2 & 2.5 & 238.2 \\
\hline El Centinela & 17.2 & 9.3 & 4.9 & 793.7 \\
\hline
\end{tabular}

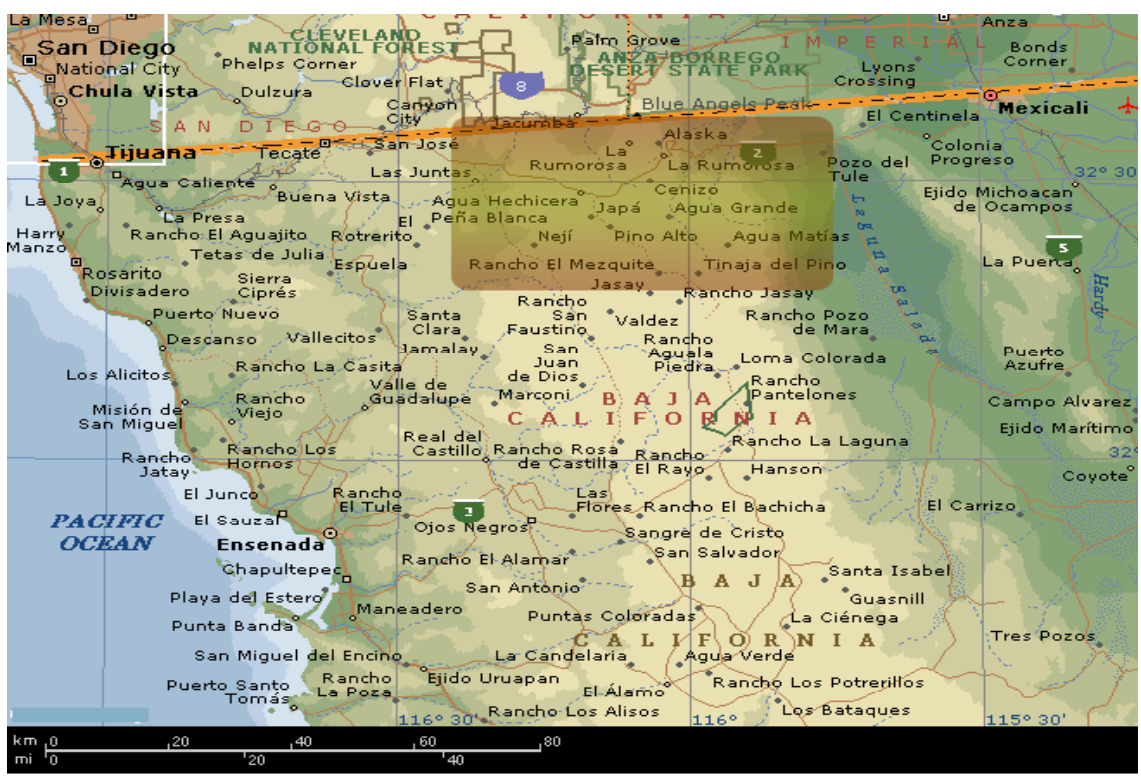

Figure 2: $\quad$ The wind study area in Baja California, Mexico [6]. 
To determine the location of a wind farm one must measure the daily and seasonal wind velocity at various locations. Wind velocity is also affected by the terrain and elevation. For this reason it is important to install one or several automatic meteorological stations that collect data such as humidity, solar radiation, and other climatic elements that could be relevant to each site.

Based on those studies Mexican specialists have concluded:

- Baja California has the potential to produce electric energy using wind power.

- Jacume and Pino Suarez are the areas with the highest potential for energy production.

- Specific studies for these areas must be carried out.

Several wind projects are being proposed in Baja California:

A) Short-term: A pilot project in the area described, with major potential that possesses the following characteristics:

- Four 1,500 kW wind turbines

- Annual production of $15,768 \mathrm{MWh} / \mathrm{y}$

- Plant factor of 0.3

- Two hectares of land

- An approximate investment of U.S. \$6 million

B) Medium-term: Development of a wind farm of $50 \mathrm{MW}$ capacity to supply several state government agencies:

- $\quad 341,500 \mathrm{~kW}$ generators

- Annual production of $134,000,000 \mathrm{kWh} / \mathrm{y}$

- Plant factor of 0.3

- 200 hectares of land

- An approximate investment of U.S. $\$ 50$ million

The Baja California 2000 project was proposed by Fuerza Eolica S.A. de C.V. in partnership with Enron Wind Corporation (U.S.), with an estimated cost of U.S. $\$ 170$ million [7]. The project aimed at producing and supplying nonpolluting, reliable electric energy with a peak production capacity of $120 \mathrm{MW}$ in the town known as La Rumorosa. This project would allow the five state municipalities of Baja California (Tijuana, Mexicali, Ensenada, Tecate, and Rosarito) a savings equivalent to 15 percent of the electricity costs for public lighting in its first twenty years of operation. The project planned to have an initial capacity of $60 \mathrm{MW}$, made up of two $30 \mathrm{MW}$ capacity modules and two future modules of the same capacity for a combined capacity of $120 \mathrm{MW}$. The wind generators would produce in excess of 300 million $\mathrm{kWh}$ per year. 
In 2003 Spanish investors visited Baja California to analyze the feasibility of constructing a $250 \mathrm{MW}$ wind farm at the Cañon de San Martin in the Valle de la Trinidad [8]. This project could potentially generate 4,000 MW with an investment of U.S. \$250 million.

The rugged topography of the La Rumorosa area, with several canyons and many ravines, dictates extensive and highly site specific wind surveying in order to assess the overall wind power potential. Given the natural secrecy and reluctance of any commercial developer active in the area to share data, further resource assessment of the wind resource will require public funding and coordination with Mexican government agencies.

\subsection{Solar energy}

Solar photovoltaic electricity is widely used for lighting, communications, and appliances such as refrigerators throughout the peninsula in rural areas and small towns not connected to an electric grid. Some fishing cooperatives have also installed solar-based and hybrid solar-wind systems in isolated fishing camps. $\mathrm{CFE}$, in collaboration with the Instituto de Investigaciones Electricas (IIE), has collected information on the maintenance requirements and long-term availability of PV systems. In the long term, the CFE-IIE collaboration may be expanded to develop several hundred MW of solar electricity nationwide within the context of a distributed generation project. A shorter term project will include the development of a grid-connected 1-MW photovoltaic array at a Mexicali substation. There is also a great potential for using solar photovoltaics for water pumping, which is carried out in a very small scale in the valley of Mexicali.

To take advantage of the excellent insulation in the state of Baja California, CFE studied the technical and economic feasibility of integrating a solar steam system to a conventional gas-fired combined cycle generating plant. A field of parabolic trough solar thermal collectors would be used to produce the steam. The concept, known as the Integrated Solar Combined Cycle System (ISCCS), was incorporated into the tender requirements issued by CFE with a 25 solar component at the Rosarito III generation plant, at Rosarito, Baja California. It is scheduled to enter in service by April of 2011.

The National Meteorological Service of Mexico (SMN) has a net of monitoring stations measuring and recording solar irradiance. Data is averaged over 10 minute intervals. Six stations in Baja California have been operational since 2000:

- $\quad$ Emilio Lopez Zamora dam (Ensenada)

- Abelardo L. Rodríguez dam (Tijuana)

- Mexicali

- San Quintín

- Bahia de los Angeles

- Gustavo Diaz Ordaz 
The data in Figure 3 was collected from all stations except the Gustavo Diaz Ordaz station for 2003 [9]. The Bahia de Los Angeles site shows the highest solar radiation in the region, followed by Mexicali.

\section{Solar Radiation 2003}

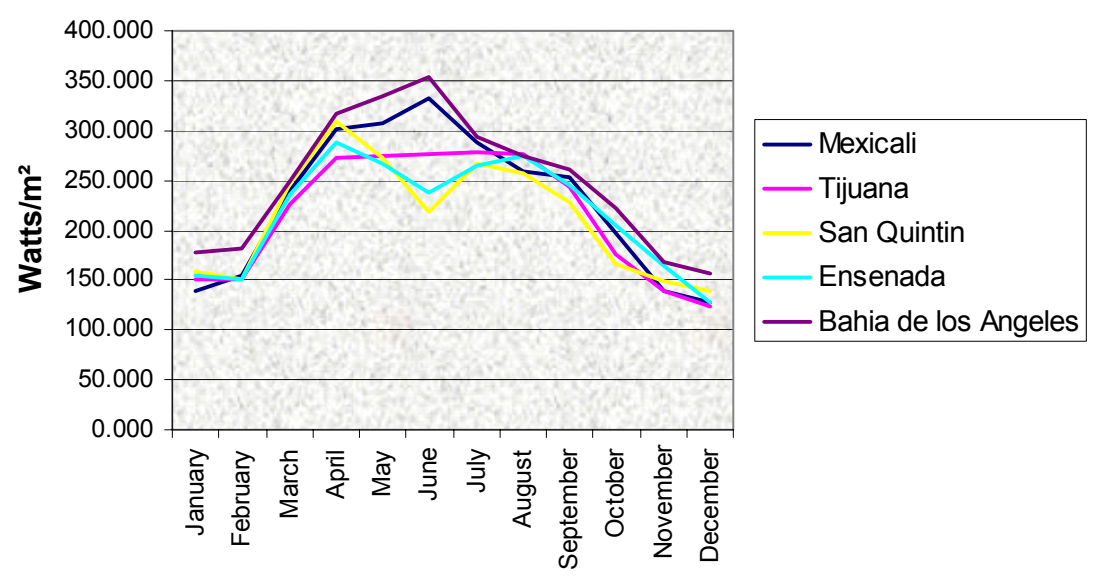

Months

Figure 3: $\quad$ Solar radiation from several monitoring stations located in Baja California for 2003.

\subsection{Micro-hydroelectrics in the Valley of Mexicali}

Twenty years ago national studies were carried out [10] to explore the possibility of installing micro-hydroelectric plants in Mexico. In this analysis, the valley of Mexicali was assigned 7.5 MW Technical Potential utilizing the irrigation canal system in Mexicali.

A later study [11] was conducted to evaluate the supply of electricity to the Autonomous University of Baja California's (UABC) academic and administrative buildings located in the city of Mexicali using micro-hydroelectric units installed in selected locations on the valley's irrigation canals. The study showed that once established the system could provide the $5 \mathrm{MW}$ demand required by $\mathrm{UABC}$.

The two projects have a Technical Potential of 12.5 MW.

\section{Barriers and drivers}

In order to exploit the full potential of renewable energy resources in Baja California, a series of barriers and drivers will need to be addressed 


\subsection{Cross border transmission capacity}

At the current time, only about $800 \mathrm{MW}$ of transmission capacity exists between Baja California, Mexico and California, USA. Most of this capacity is already utilized. In order to take advantage of new renewable energy generation in Mexico, increased cross border transmission capacity will be needed.

\subsection{Renewable Energy Credits}

California utilities, including San Diego Gas and Electric (SDG\&E), are required to meet a portion of their demand from approved renewable energy sources. They receive a Renewable Energy Credit (REC) that counts towards meeting this requirement. At the present time, renewable energy sources in Mexico do not count towards the renewable energy credit. This is a significant barrier for companies to develop renewable projects in Mexico and a major barrier for SDG\&E to buy energy from renewable sources originating in Baja California.

\subsubsection{Production tax credit}

The production tax credit (PTC) is very important for wind projects to be cost effective. Currently, the PTC can only be applied to US-based projects. This is clearly a major barrier to the development of wind power in Baja California, even though the resultant energy would be sold to California. This requires a change in federal legislation.

\subsection{Binational energy planning}

Although energy facilities located on one side of the border could have environmental impacts on the other side, there is no mechanism to incorporate these cross border effects. Some mechanism is needed to take into account cross border impacts from energy production and distribution, even if the energy resource is a renewable one. Some headway has been made in this area via the San Diego Association of Governments' (SANDAG), the Border Energy Issues Group and the Border Governor's Energy Working Group, but more needs to be done.

Despite these barriers, there are definite advantages to develop enhanced cross border energy capacity to better utilize the renewable potential in Baja California. Chief among these is the large renewable potential that exists in northern Baja California in the form of solar, wind and geothermal. In addition to the renewable resources themselves, land may be less expensive than in California and there could be certain tax advantages to locating a project in Mexico.

The above discussion focuses primarily on cross border transfer of renewably generated electricity from Baja California to California. From an energy, environment and economic perspective, northern Baja California is a vital part of the greater San Diego Region. As indicated earlier in this chapter, the need for electricity in Baja California is growing rapidly and renewable technologies have a role to play to meet this demand. However, before this potential can be developed, certain barriers need to be addressed. 


\subsection{CFE and renewables}

CFE, as the only entity allowed to generate electricity in Mexico for general distribution, should consider increasing the portion of renewable energy in its mix of resources for Baja California. The main issue for CFE - as it is on the US side of the border - is the relatively high capital cost of installation for solar and wind technologies. However, in Baja California, where the primary fuel for power generation is natural gas that must be imported, renewable technologies may be more cost competitive than in other regions of Mexico. It may also be possible for CFE to develop a renewable portfolio standard, similar to what exists in California.

\section{Full renewable potential for Baja California}

This paper has not addressed the full potential for renewable energy development in Baja California. For example, we have not analyzed the potential contribution of solar hot water to replace electricity, or the possible contribution of rooftop $\mathrm{PV}$ in commercial and residential buildings. Nor have we done an analysis of the regions appropriate for central station solar generation. There are potential wind sites that need further analysis. These issues we hope to address in a future study, but clearly from our present study, there is considerable potential for significant renewable energy development in Baja California.

The main drivers for renewable energy development in Baja California are:

- The high cost on imported natural gas.

- The abundant solar and wind potential of the region.

- The resulting reduction of air pollution by increasing the amount of renewable energy utilized.

- The potential creation of new industries.

\section{References}

[1] Advisory Council for the Promotion of Renewable Energies (COFER). Sener. www.sener.gob.mx.

[2] Alvarez, M. "Climatología de la Sierra de San Pedro Martir". Desert Fishes Council $15^{\circ}$ Annual Simposio, November. 1983

[3] Constitución Politica de los Estados Unidos Mexicanos, ed. Porrua, México, D.F. 2005

[4] Alonso, E. H., Cerro Prieto :Una alternativa en el desarrollo energético, Memoria de la Reunión Nacional sobre la Energia y el Confort, eds. Garcia F.C., Instituto de Ingenieria, UABC, Mexicali, B.C., pp. 314-319. 1988.

[5] Scott, A., Bialek, T., Geier, D., Houston, J.D., Quintero N.M., Resley, R., Rohy D.A., Swedler, A., Tanaka, S., Gin C. \& Zeng, K., Potential for renewable energy in the San Diego Region, ed. San Diego Regional Renewable Energy Group, August 2005, Sand Diego, CA, USA. 
[6] Energy Information Systems (SIE). Sener, www.sener.gob.mx.

[7] Gottfried Carlos. "Baja California 2000, Energía eólica para el Estado de Baja California”, Fuerza Eólica S.A de C.V.7 Noviembre. Mexicali, Baja California. 1999

[8] Rivero, M. "Promueven Planta eolica". La Crónica, Mexicali Baja California, 16 de junio, pp 2/F. 2002

[9] SMN. Base de datos sobre radiación solar del 2003. Sistema Meteorológico Nacional. México. 2003.

[10] Ferran, R. F. "Estimación del potencial hidroenergético de los distritos de riego del país", Instituto de Investigaciones Eléctricas (IIE). Informe IIE/42/3988/101/F. Marzo. Palmira, Morelos, México. 1986

[11] Quintero, N.M López, R.M., Microhydroelectric plants in the valley of Mexicali (Chapter 15) Energy and Environment in the California BajaCalifornia Border Region, ed. A. Sweedler, Paul Ganster, and P. Bennett, IRSC, SDSU, pp. 129-132, 1995. 